\title{
Variability of SST and ILD in the Arabian Sea and Sea of Oman in Association with the Monsoon Cycle
}

\author{
Sartaj Khan $\mathbb{D}^{1,2}$ Shengchun Piao, ${ }^{1,2}$ Imran U. Khan $\mathbb{D D}^{1}{ }^{1}$ Bingchen Xu, ${ }^{1,2}$ Shazia Khan, \\ Muhammad Asim Ismail, ${ }^{1}$ and Yang Song ${ }^{1,2}$
}

${ }^{1}$ College of Underwater Acoustic Engineering, Harbin Engineering University, Harbin 150001, China

${ }^{2}$ Acoustic Science Technology Laboratory, Harbin Engineering University, Harbin 150001, China

${ }^{3}$ Department of Biological Sciences, International Islamic University, Islamabad 44000, Pakistan

Correspondence should be addressed to Yang Song; song_yang@hrbeu.edu.cn

Received 5 March 2021; Revised 2 May 2021; Accepted 12 June 2021; Published 23 June 2021

Academic Editor: Bhawani Shankar Chowdhry

Copyright (c) 2021 Sartaj Khan et al. This is an open access article distributed under the Creative Commons Attribution License, which permits unrestricted use, distribution, and reproduction in any medium, provided the original work is properly cited.

Sea surface temperature (SST) and isothermal layer depth (ILD) are important oceanic parameters and could play a significant role in understanding the upper thermal structure as well as improve the predictive capability of monsoons in the tropical oceans. In a disparate departure from the past research, the present study investigates the seasonal variability of SST and ILD in association with the monsoon cycle in the Arabian Sea and Sea of Oman regions by examination of Argo datasets for 2016-17. In this study, the ILD climatology is determined from temperature profiles provided by the Argo floats based on a threshold technique $\left(T(z) \geq \mathrm{SST}-1^{\circ} \mathrm{C}\right)$ to investigate the region of stronger and weaker monsoon wind forcing. For SST, values of temperature are used nearest to the sea surface (depth $(z) \leq 5 \mathrm{~m}$ ). The region is split into four distinct zones for an accurate description of the monsoon cycle: the south Arabian Sea, the central Arabian Sea, the north Arabian Sea, and the Sea of Oman. It is observed that summer monsoon is more pronounced in the south-central basin of the Arabian Sea, where ILD is deepening ( $>100 \mathrm{~m}$ in September 2016) mainly due to stronger wind forcing in this region. On the contrary, the Sea of Oman region is displayed with smaller ILD amplitude ( $<10 \mathrm{~m}$ in June 2016) with larger SST, meaning that this region is weakly influenced by the summer monsoon. The seasonal relationship established between ILD variability and monsoon cycle for 2016-17 shows that ILD could be a useful indicator for predicting summer monsoon in the Arabian Sea regions. Our analysis results indicate that the dynamics for SST variability are different in these regions and are influenced either by large-scale atmospheric forcing, such as the El NiñoSouthern Oscillation (ENSO) and the Indian Ocean Dipole (IOD), or by the effects of mesoscale variations occurring along the Oman-Arabian coast.

\section{Introduction}

The dynamics of sea surface temperature (SST) variability in the Indian Ocean vary in different seasons and regions. Previous research shows that the strong seasonality of the SST is the result of the combined effect of oceanic and atmospheric processes at the air-sea interface (mainly controlled by seasonal changes in the incoming solar radiation), and the oceanic and atmospheric circulation such as El Niño/La Niña-Southern Oscillation (ENSO) in the Pacific Ocean [1-3] or the internal independent mechanism such as Indian Ocean Dipole (IOD) can affect the interannual variability of SST [4-8]. The annual cycle of monsoons mainly exhibits bimodal distribution and significantly affects the upper thermal structure, which is mainly responsible for regional circulation and heat/salt transport in the Arabian Sea [9]. The annual cycle of SST in the tropical Indian Ocean mainly consists of four stages: (1) a warming stage from about February to May; (2) cooling from May to August; (3) warming from August to October; and (4) cooling from October to January (Figure 1). This pattern is in contrast to the annual cycle of the SST in most of other regions of the world ocean, which display only two phases: warming during spring and summer; and cooling during autumn and 


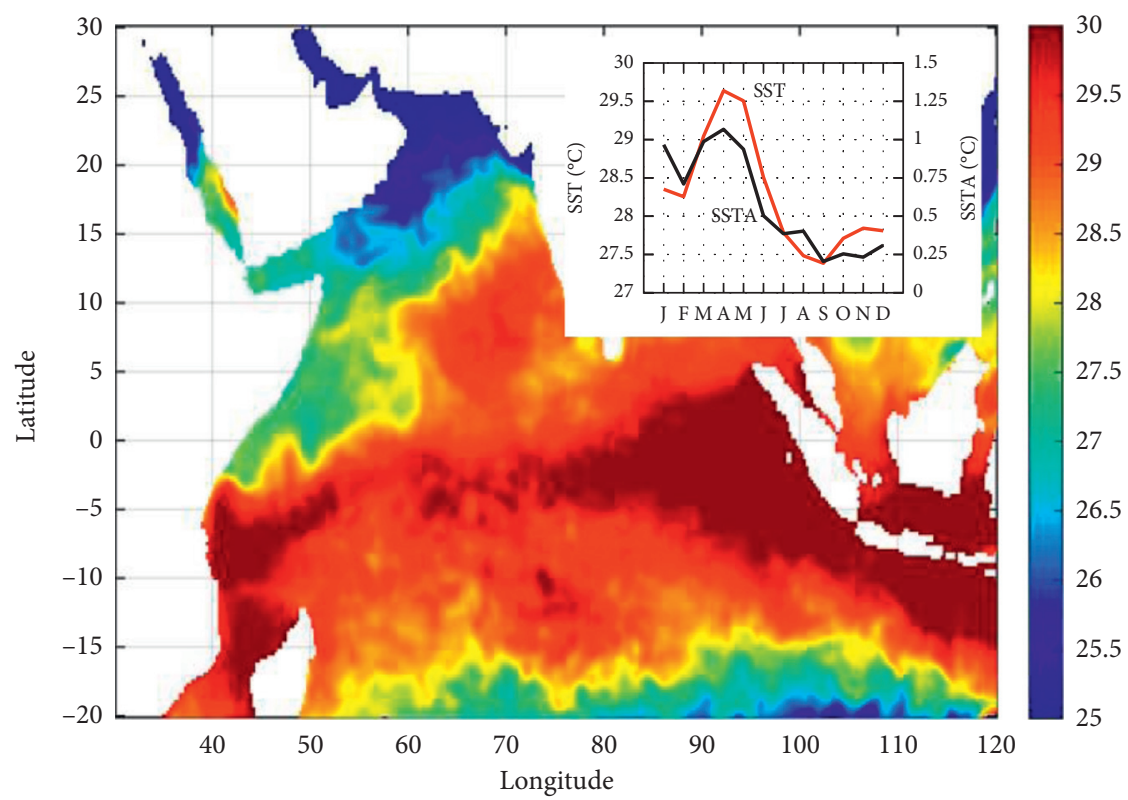

(a)

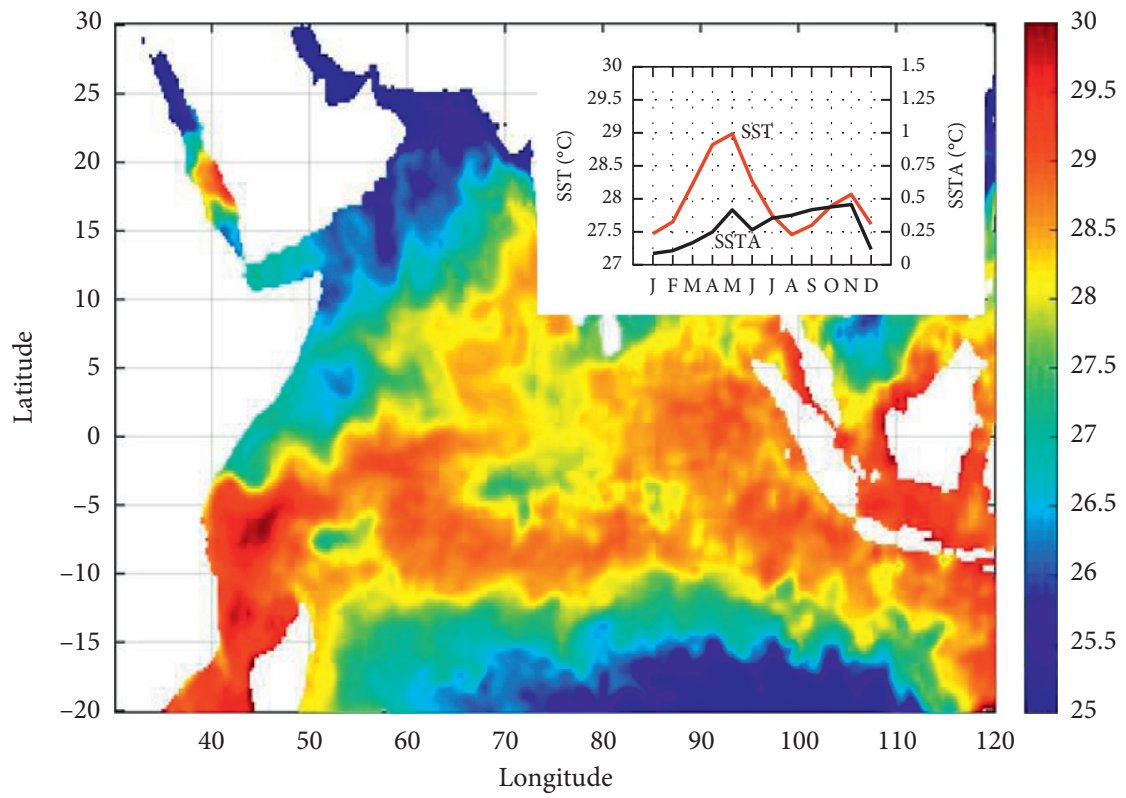

(b)

FIgURE 1: Annual mean SST in the tropical Indian Ocean for 2016 (a) and 2017 (b). Monthly mean SST and SST anomaly cycles are shown at the top right of the map data. Datasets were derived from the NOAA OISST (Optimum Interpolation Sea Surface Temperature) blended product, version 2.1. This product includes satellite observations Advanced Very High-Resolution Radiometer (AVHRR) and Advanced Microwave Scanning and is available from 1981, with a $0.25^{\circ} \times 0.25^{\circ}$ spatial resolution and daily temporal interval.

winter. All available evidence suggests that this unusual behavior of the tropical Indian Ocean is due to the influence of the southwest monsoon (summer season) that dominates the Arabian Sea during the northern hemisphere summer. The energetic circulation of wind during this period is known to have an effect on the SST. In the coastal regions, upwelling typically occurs, which brings up colder water and then spreads offshore [10], whereas, in the open sea, the loss of energy and heat on the surface lower the SST. These changes in SSTs and winds over the oceanic may have influence on weather and climate of the adjacent land area and Indian rainfall $[3,11]$. Recently, the SST in the east Pacific Ocean was strongly influenced by the powerful El Niño in 2016 [4, 12] and the weak La Niña in 2017 [13]. In early 2016, the tropical Indian Ocean warmed up in the presence of El Niño and the maximum SST (monthly mean) increased beyond $29.5^{\circ} \mathrm{C}$ in April-May (Figure 1(a)). The powerful El Niño and weak La Niña caused extreme negative and weak positive IOD events in the Indian Ocean during 2016 and 2017, respectively. The extreme negative and weak 
positive IOD events have had a significant impact on the monsoon cycle in the Indian Ocean and have caused more flood and rainfall in many parts of Australia, Indonesia, and the Indian subcontinent, as well as drought conditions in East Africa [12, 14]. As a result, almost half of the world's population living in this region has an impact on food production, water insecurity, and even human health.

Apart from SST, isothermal layer depth (ILD) is an important oceanic parameter that could help us understand the effects of monsoonal winds variability in the tropical Indian Ocean. It is, therefore, critical to document ILD variability and its relation to the monsoon cycle, because it may have a significant influence on summer monsoon qualitative predictability. Using various Argo and satellite datasets, an attempt is made in the present study to investigate the influence of monsoons on SST cycle and ILD amplitude in the Arabian Sea and Sea of Oman regions. It is important to highlight that the SST cycle in the south-central basin of the Arabian Sea is mainly affected by the ENSO and IOD events. A notable feature of the Arabian Sea circulation is the presence of strong (weak) upwelling along the OmanArabian coast that occurs in late spring and peaks in summer. The low upwelling warms SST along the OmanArabian coast, which is considered important for Indian monsoon rainfall and remains a key area in this study. We believe that these results, based on satellite and Argo datasets, will be useful for scientists engaged in research on atmospheric and oceanic studies, air-sea interaction studies, and monsoon studies. The rest of the paper is organized as follows: Section 2 describes the area under investigation, as well as various satellite and Argo datasets, followed by a brief derivation of ILD and SST from temperature profiles provided by Argo floats. Section 3 describes the results and discussion, including SST and ILD variability in association with monsoon cycles in the Arabian Sea and Sea of Oman regions. Finally, the main findings are summarized in Section 4.

\section{Materials and Methods}

2.1. Study Area. The Arabian Sea is the northwestern part of the tropical Indian Ocean with land boundaries in the west, north, and east. The geographical extent of the Arabian Sea is shown in Figure 2. As shown in the figure, the sea is bounded by India (to the east), Pakistan and Iran (to the north), and the Arabian Peninsula in the west. In the southwest, the sea is connected with the Red Sea through the Gulf of Aden, while, in the northwest, it is connected with the Persian Gulf through the Sea of Oman and Strait of Hormuz. The Sea of Oman (formerly known as the Gulf of Oman) extends between 22 and $26^{\circ} \mathrm{N}$ and $56-60^{\circ} \mathrm{E}$. It is broad and deep $(240 \times 450 \mathrm{~km}$ and from $200 \mathrm{~m}$ to typically $4000 \mathrm{~m}$ deep at the Arabian Sea) and opens on the Arabian Sea and the Indian Ocean at its southeast part. The areas under investigation are identified by four distinct zones including three in the Arabian Sea, south Arabian Sea (Zone 1; Eq- $5^{\circ} \mathrm{N} /$ $54-61^{\circ} \mathrm{E}$ ), central Arabian Sea (Zone 2; $11-15^{\circ} \mathrm{N} / 57-69^{\circ} \mathrm{E}$ ), and north Arabian Sea (Zone $3 ; 17-23^{\circ} \mathrm{N} / 60-67^{\circ} \mathrm{E}$ ), and one in the Sea of Oman (Zone 4; $23-25^{\circ} \mathrm{N} / 58-65^{\circ} \mathrm{E}$ ).

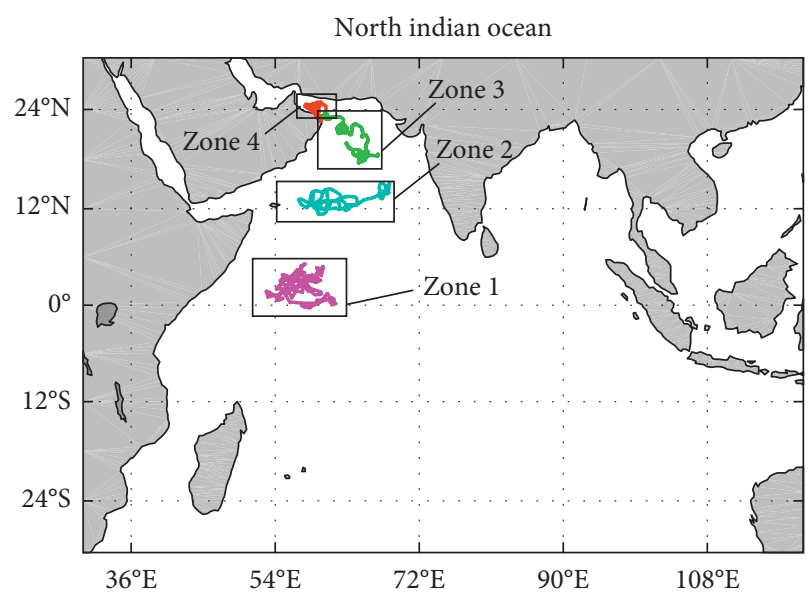

FIgURE 2: Geographical extent of the north Indian Ocean; the areas under investigation are marked with black boxes representing the south Arabian Sea (Zone 1; Eq $-5^{\circ} \mathrm{N}, 54-61^{\circ} \mathrm{E}$ ), central Arabian Sea (Zone $2 ; 11-15^{\circ} \mathrm{N}, 57-69^{\circ} \mathrm{E}$ ), north Arabian Sea (Zone $3 ; 17-23^{\circ} \mathrm{N}$, $60-67^{\circ} \mathrm{E}$ ), and Sea of Oman (Zone $4 ; 23-25^{\circ} \mathrm{N}, 58-60^{\circ} \mathrm{E}$ ). Trajectories of Argo floats are shown within the boxes.

\subsection{Data Sources}

2.2.1. Argo Data. The most important data for this study are temperature and salinity profiles provided by Argo floats. The recent expansion of the Argo array in the Indian Ocean has enhanced the coverage and resolution of temperature and salinity profiles [15-17]. Argo provides greater spatial and temporal resolution relative to other in situ observations (i.e., ship-based measurements, gliders, and moorings). Usually, Argo floats sample during their ascent phase and stop sampling 3 to $4 \mathrm{~m}$ below the sea surface. The cycle period (the time interval between two surfacings of the float) of the floats ranged from 3 to 10 days. In this study, T/S (temperature/salinity) profiles of four Argo floats were used for SST and SSS (sea surface salinity) measurements. All these profiles were obtained from January 01, 2016, to December 31, 2017, and were periodically downloaded from the Ifremer website [18]. As the dynamics of SST variability are different for different seasons and regions, therefore, monthly mean of SST data was analyzed separately for each region in this paper. Reanalysis of time-space variations of SST and SSS was performed in Matlab version "Matlab r2017a". Before analysis, the datasets were linearly interpolated with a one-meter depth interval. For SST and SSS, values of temperature and salinity were used closest to the sea surface (depth $(z) \leq 5 \mathrm{~m}$ ), as it would be the nearest surface observation that would be comparable to both satellite SST and SSS measurements [19]. Details of Argo floats used in this study are described in Table 1.

2.2.2. Satellite Data. In addition to Argo floats, various satellite datasets were used in this study. The monthly mean sea-air temperature (SAT) data at 1 atmospheric pressure were provided by NCEP Global Data Assimilation System (GDAS) and are available at $2.5^{\circ}$ (latitude) $\times 2.5^{\circ}$ (longitude) spatial resolution. In addition, the precipitation and wind 
Table 1: Details of Argo floats used in the study.

\begin{tabular}{|c|c|c|}
\hline $\begin{array}{l}\text { Argo float } \\
\text { (WMO ID) }\end{array}$ & Deployment region & Description \\
\hline 2902659 & $\begin{array}{l}\text { South Arabian Sea } \\
\text { (Zone 1) }\end{array}$ & $\begin{array}{l}\text { This float was deployed on } 28 \text { October } 2014 \text { in the south Arabian Sea region near the equator } \\
\text { around } 1^{\circ} \mathrm{N}, 65.2^{\circ} \mathrm{E} \text { by First Institute of Oceanography (Qingdao China) as Argo China } \\
\text { Project. The profiler cycle period of this float was } 240 \mathrm{~h} \text { with maximum } 2000 \mathrm{~m} \text { depth. The } \\
\text { float provided a total of } 201 \text { profiles out of which } 72 \text { profiles between EQ- } 5^{\circ} \mathrm{N}, 56-61^{\circ} \mathrm{E} \text { were } \\
\text { analyzed. Trajectory of the float is shown in Figure } 2 .\end{array}$ \\
\hline 2902123 & $\begin{array}{c}\text { Central Arabian Sea } \\
\text { (Zone } 2)\end{array}$ & $\begin{array}{l}\text { This float was released on } 10 \text { March } 2014 \text { in the central Arabian Sea region around } 14^{\circ} \mathrm{N}, 67^{\circ} \mathrm{E} \\
\text { by Indian National Centre for Ocean Information Services (INCOIS) as Indian Argo Project. } \\
\text { The profiler cycle period of this float was } 10 \text {-days with a maximum of } 2000 \mathrm{~m} \text { depth. The float } \\
\text { provided a total of } 201 \text { profiles out of which } 72 \text { profiles between } 11 \text { and } 15^{\circ} \mathrm{N}, 57-69^{\circ} \mathrm{E} \text { were } \\
\text { analyzed. Trajectory of the float is shown in Figure } 2 .\end{array}$ \\
\hline 2902062 & $\begin{array}{l}\text { North Arabian Sea } \\
\text { (Zone 3) }\end{array}$ & $\begin{array}{l}\text { This float was launched on } 21 \text { December } 2015 \text { in the north Arabian Sea region around } 23^{\circ} \mathrm{N} \text {, } \\
60.25^{\circ} \mathrm{E} \text { by Naval Oceanographic Office (NAVO) as U.S. Argo Project. The cycle period of this } \\
\text { float was } 3 \text { to } 5 \text { days, with a maximum of } 1500 \mathrm{~m} \text { depth. The float provided a total of } 293 \\
\text { profiles out of which } 187 \text { profiles between } 17 \text { and } 23^{\circ} \mathrm{N}, 60-67^{\circ} \mathrm{E} \text { were analyzed. Trajectory of } \\
\text { the float } 2902062 \text { is shown in Figure } 2 .\end{array}$ \\
\hline 2902065 & Sea of Oman (Zone 4) & $\begin{array}{l}\text { Trajectory of the float } 2902065 \text { is shown in Figure } 2 \text {. This float was deployed on } 09 \text { November } \\
2015 \text { in the Sea of Oman region around } 24^{\circ} \mathrm{N}, 58.9^{\circ} \mathrm{E} \text { by Naval Oceanographic Office (NAVO) } \\
\text { as U.S. Argo Project. The Argo drift had a } 3 \text { to } 5 \text {-day cycle with a maximum of } 1500 \mathrm{~m} \text { depth. } \\
\text { The float provided a total of } 297 \text { profiles out of which } 198 \text { profiles between } 23 \text { and } 25^{\circ} \mathrm{N} \text {, } \\
58-60^{\circ} \mathrm{E} \text { were analyzed. }\end{array}$ \\
\hline
\end{tabular}

speed at $10 \mathrm{~m}$ above sea surface (U10) were used. The monthly mean precipitation data $(\mathrm{mm} /$ day $)$ were derived from the Global Precipitation Climatology Project Version 2.3 (GPCPv2.3). The GPCPv2.3 data were available with airsea $2.5^{\circ}$ (latitude) $\times 2.5^{\circ}$ (longitude) spatial resolution $[20,21]$. The Woods Hole Oceanographic Institution (WHOI) Objectively Analyzed Fluxes (OAFlux) project provided the mean wind speed at $10 \mathrm{~m}$ above sea surface. The OAFlux is an ongoing research and development project for global air-sea fluxes (http://oaflux.whoi.edu). The monthly mean SSS data were obtained from the SMAPv3 (Soil Moisture Active Passive version 3; [22]) and are accessible online at http://www.remss.com/missions/smap. Although SMAP was designed to measure space soil moisture, its $\mathrm{L}$-band radiometer can also be used to measure SSS.

2.3. Criteria for ILD Determination. In the Arabian Sea, the propagation of the fluctuations in the thermocline is a key factor in maintaining the SST cycle. The changes in the thermocline depths are represented by the changes in the ILD. In this study, the threshold technique was used to derive the ILD from the temperature profiles provided by the Argo floats. For ILD, the threshold technique determines the depth at which the temperature $(\Delta T)$ alters by a fixed value relative to the value at a near-surface reference depth [23]. The ILD climatologies have been created in the past by many authors for individual ocean basins [24-26]. The criterion for determining the isotherm temperature varies from $1^{\circ} \mathrm{C}$ $[26,27]$ to $0.8^{\circ} \mathrm{C}[28,29]$ to $0.5^{\circ} \mathrm{C}[30-32]$ to $0.2^{\circ} \mathrm{C}$ [33-37]. In this study, the ILD was estimated by using Rao et al. [26] formulation. The reference level, however, varies from nearsurface [30] to $10 \mathrm{~m}$ depth [36]. The criteria used in this research were the depth range, where the temperature of given depth $(z)$ is within $1^{\circ} \mathrm{C}$ of the near-surface temperature, i.e., ILD $=$ depth, where $\mathrm{T}(\mathrm{z}) \geq \mathrm{SST}-\Delta \mathrm{T}$, and $\Delta T=1^{\circ} \mathrm{C}$
$[26,27]$. Seawater density $\delta(T, S, z)$ was determined from temperature and salinity profiles, where $T, S$, and $z$ represent temperature $\left({ }^{\circ} \mathrm{C}\right)$, salinity, and depth $(\mathrm{m})$, respectively.

The above criterion is applied to a single temperature and salinity profile in the Arabian Sea and the Sea of Oman regions (Figure 3). As can be seen from the Figure 3(b), the appearance of the halocline layer just below the surface layer indicates a density variation within the isothermal layer. It means that the difference between isothermal and isopycnal layers depth is positive, which is often in the tropics [38]. As discussed later in this study, the deeper isothermal layer in the Arabian Sea is most likely due to strong wind mixing activity at the air-sea interface, which represents stronger monsoonal force in the Arabian Sea region during the summer compared to the Oman Sea region, where the depth of the isothermal layer is always shallow.

\section{Results and Discussion}

3.1. South Arabian Sea. Monthly variations of SST and SAT in the south Arabian Sea region in 2016 and 2017 are shown in Figures 4(a)and 4(b), respectively. As shown in Figure 4(a), this region appears with a semiannual cycle in SST distribution, where low SST occurs in both summer and winter monsoons. The annual minimum SST reaches $26.8^{\circ} \mathrm{C}$ in July 2016 during summer monsoon and in January 2017 during winter monsoon. On seasonal average, the winter monsoon warming is not similar and shows different variability in SST in both 2016 and 2017. Significant variations in the SST cycle are observed during the winter monsoon when the surface temperature is warmer by almost $2^{\circ} \mathrm{C}$ during winter months (January to February) in 2016 than in 2017. It is observed that variability of SAT patterns is consistent with SST and remains high at the beginning of 2016 compared to 2017. This warming in SST during 2016 is concurrent with the extreme El Niño event that occurred in 


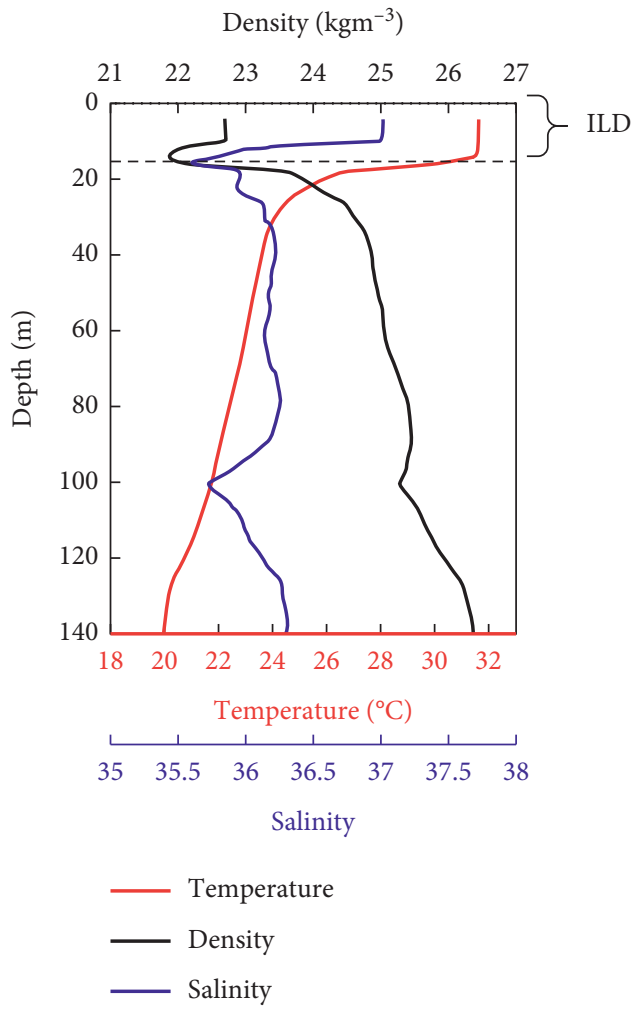

(a)

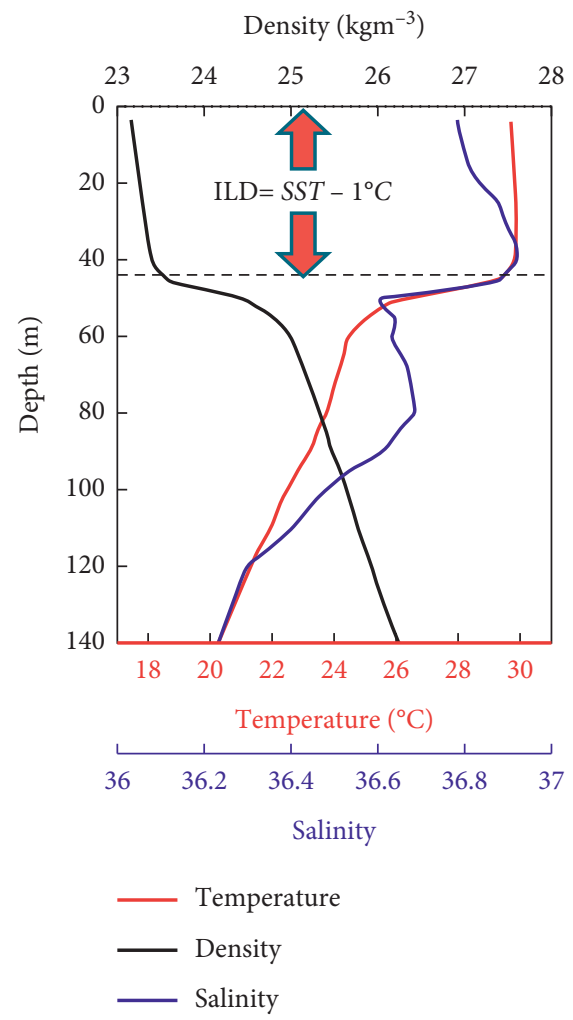

(b)

Figure 3: Typical profiles of temperature and salinity from the Sea of Oman and Arabian Sea regions. ILD is calculated from the depth, where the temperature decreases by $1^{\circ} \mathrm{C}$ from the temperature at the sea surface (or reference temperature). Float position was $24.8^{\circ} \mathrm{N}, 59.8^{\circ} \mathrm{E}$ in July 2017 in the Sea of Oman (a) and $22.5^{\circ} \mathrm{N}, 62.5^{\circ} \mathrm{E}$ in June 2016 (b).

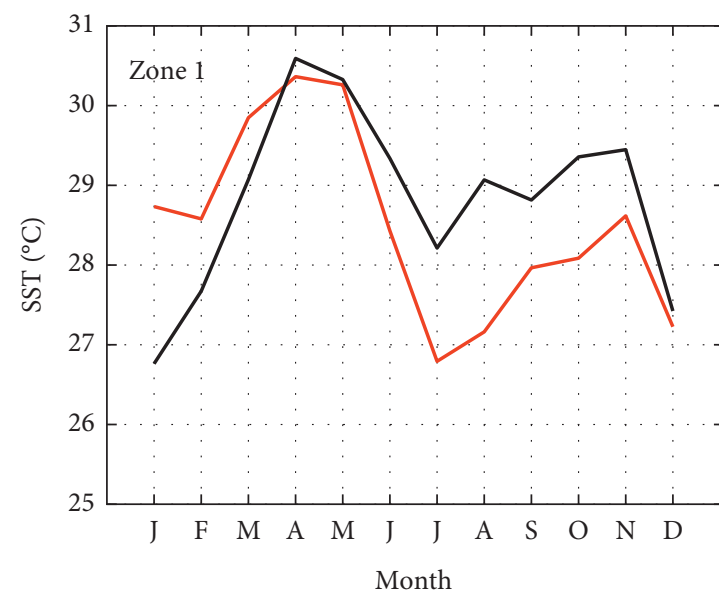

2016

2017

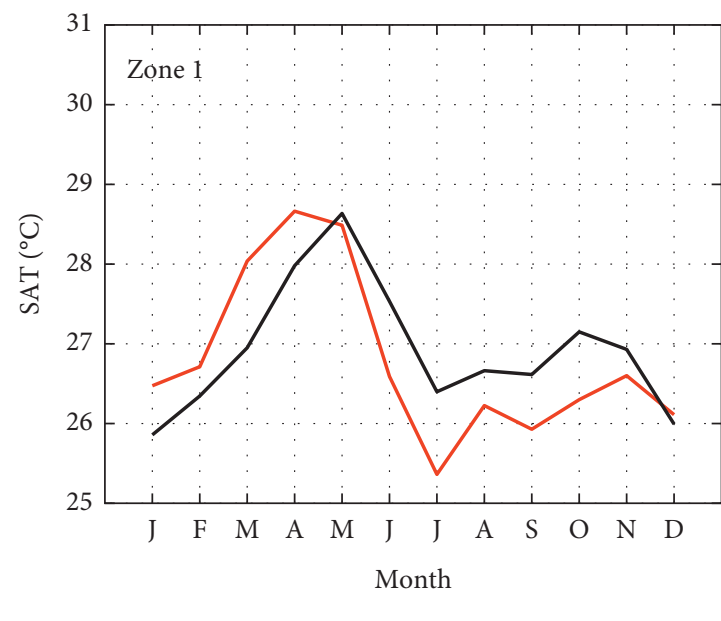

2016

2017

(a)

(b)

FIgUre 4: (a) Monthly mean cycle of SST in the south Arabian Sea (Zone 1) during 2016-17 based on Argo datasets. (b) Monthly mean cycle of SAT at 1 atmospheric pressure in the South Arabian Sea (Zone 1) during 2016-17. SAT datasets were provided by NCEP Global Data Assimilation System (GDAS), and they are available at $2.5^{\circ} \times 2.5^{\circ}$ spatial resolution. 
the Pacific Ocean in early 2016 [12]. The strong El Niño significantly affected the equatorial Pacific Ocean and the tropical Indian Ocean, where positive SST anomalies persisted throughout 2016 (Figure 1(a)).

During the presummer monsoon, SST is getting warm due to clear skies, rise in solar insolation, and reduced winds (WS $<3 \mathrm{~m} / \mathrm{s}$ in April; Figure 5(a)). These moderate winds and strong surface heating are instrumental in warming up the ocean surface, resulting in high surface temperature (SST $>30^{\circ} \mathrm{C}$ in April-May; Figure 4(a)). However, as shown in Figure 5(a), the wind speed shows an increasing trend as the monsoon sets. SSTgets cool and reaches above $27^{\circ} \mathrm{C}\left(28^{\circ} \mathrm{C}\right)$ on average in summer 2016 (2017) from July to September due to strong winds and cooling in the air temperature. During this period, the effect of wind force is high as compared to the premonsoon, and the turbulent mixing causes the cool surface waters to sink into a deeper layer, resulting in a deeper thermocline (up to $90 \mathrm{~m}$ ) in July-August of 2016. In comparison, the SST in this region is cooler by almost $1^{\circ} \mathrm{C}$ in 2016 than in 2017, which is concurrent with the negative (positive) IOD events in 2016 (2017) with a low (high) SST in the western tropical Indian Ocean compared to the eastern part. The strong correlation, which is observed between SST and SAT patterns, represents a strong coupling between the ocean and the atmosphere in this region. These variability patterns highlight the fundamental role of SAT on SST. Quite different behavior is, however, seen in this region, where ILD amplitude is always smaller in the winter monsoon and larger in the summer and post-summer monsoons. As can be seen from Figure 5(b), the two-year distribution of ILD reveals significant fall in ILD amplitude during the summer monsoon in 2017 than in 2016. The smaller ILD amplitude from December to March indicates the weaker nature of the convective mixing during the winter monsoon, where larger amplitude from June to September represents the dominant nature of the winds stirring and Ekman pumping during the summer monsoon. In short, the mechanisms describing the air-sea feedback, as well as the relationship between wind and thermodynamic parameters, indicate that SST is mainly driven by wind force in this region. The smaller ILD amplitude from December to March indicates the weaker nature of the convective mixing during the winter monsoon, where larger amplitude from June to September represents the dominant nature of the winds stirring and Ekman pumping during the summer monsoon.

3.2. Central Arabian Sea. Monthly cycle of SST and SAT in the central Arabian Sea region in 2016 and 2017 is shown in Figures 6(a) and 6(b), respectively. Like the south Arabian Sea, this region also exhibits a semiannual cycle of low SST in both summer and winter monsoons. The annual minimum SST reaches $26^{\circ} \mathrm{C}$ in August 2016 during the summer monsoon and $25.9^{\circ} \mathrm{C}$ in February 2017 during the winter monsoon. As in the southern basin, the two-year distribution of SST in this region has shown a remarkable warming in the 2016 winter monsoon compared to 2017. Winter SST is warmer at around $2^{\circ} \mathrm{C}$ during the winter months (January to February) in 2016 than in 2017. This trend is, however, in contrast with the late summer and autumn seasons, in which SST remained warm in 2017 compared to 2016. This warming in the SST in winter 2016 is concurrent with the extreme El Niño event that occurred in the Pacific Ocean in early 2016. The premonsoon period (April to May) in the central Arabian Sea is characterized by clear sky, light winds, deep solar insolation, and strong heat gain. In this period, SST rapidly increases and reaches $31^{\circ} \mathrm{C}$ in May 2016 (the annual high).

In the summer monsoon period, the central Arabian Sea region expresses some of the strongest and balanced winds forcing, which is characterized by strong winds, moist air, and a decrease in solar insolation due to cloudy cover. The WS is showing an increasing trend as the monsoon sets in both 2016 and 2017 (Figure 7(a)). SST gets cool and reaches $\sim 26^{\circ} \mathrm{C}$ in summer monsoon due to strong wind speed (WS $>11 \mathrm{~m} / \mathrm{s})$ and cooling in SAT $\left(<26^{\circ} \mathrm{C}\right)$. During this period, the effect of wind force is much higher than that of the premonsoon, and the turbulent mixing causes the cool surface waters to sink into a deeper layer, resulting in a deeper thermocline (ILD $120 \mathrm{~m}$ in September 2016). The two-year distribution shows almost similar patterns in SST during the first half of summer monsoon (June to July); however, the second half (August to September) shows significant cooling (about $1^{\circ} \mathrm{C}$ ) in 2016 mainly due to negative (positive) IOD events in 2016 (2017) discussed earlier in previous section. The strong correlation, which is observed between SST and SAT pattern variability, represents a strong link between the ocean and the atmosphere in this region. As can be seen from Figure 7(b), the two-year distribution of ILD shows an increase in ILD amplitude during the late summer of 2016 compared to 2017. The larger ILD amplitude (ILD $>100 \mathrm{~m}$ ) in July-September represents the dominant nature of the winds stirring and Ekman pumping during the summer monsoon. In short, the mechanisms describing the air-sea feedback, as well as the relationship between wind and thermodynamic parameters, indicate that SST is mainly driven by wind force in the central and south basins of the Arabian Sea.

3.3. North Arabian Sea. The monthly cycle of SST and SAT in the north Arabian Sea region in 2016 and 2017 is shown in Figures 8(a)and 8(b), respectively. As shown in Figure 8(a), the seasonal cycle of temperature variations in this region in the upper surface is characterized by cooling from January to February and significantly warming from May to July and postmonsoon (October to November). The winter minimum temperature reaches $24^{\circ} \mathrm{C}$ in February 2016; however, the SST is getting warm during the presummer monsoon due to a rise in solar insolation and reaches $30^{\circ} \mathrm{C}$ in June 2016 with high SSS (>36.3) because of freshwater loss due to high evaporation. A patch of high saline water (above 36 on average; see Figure 9(c)) is observed in this region during the entire period. The presence of this high saline water near the Ras al Hadd region indicates the intrusion of highly saline water from the Persian Gulf into the northern Arabian Sea via the Sea of Oman [39]. However, the wind speed shows an increasing trend during the summer monsoon (Figure 10(a)). SST is getting cool and reaches $26^{\circ} \mathrm{C}$ in 


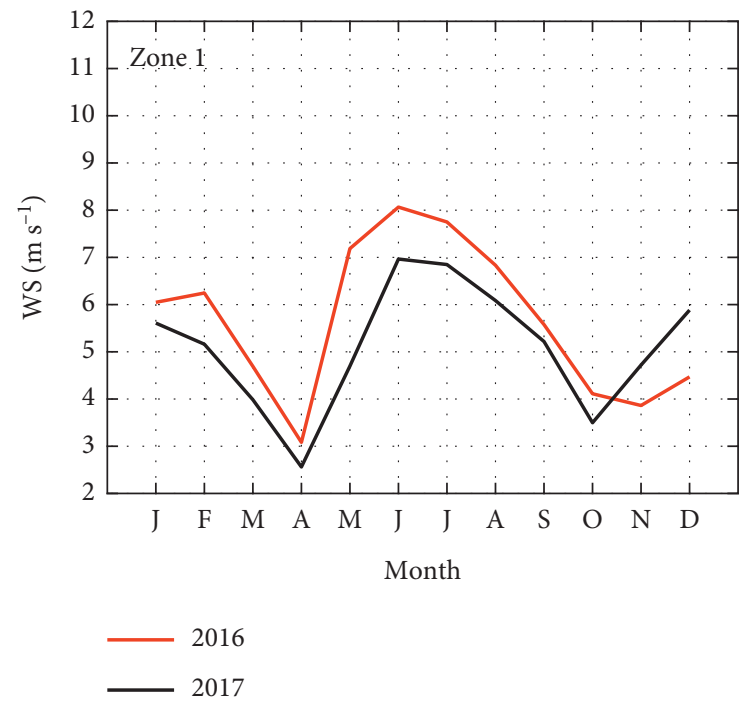

(a)

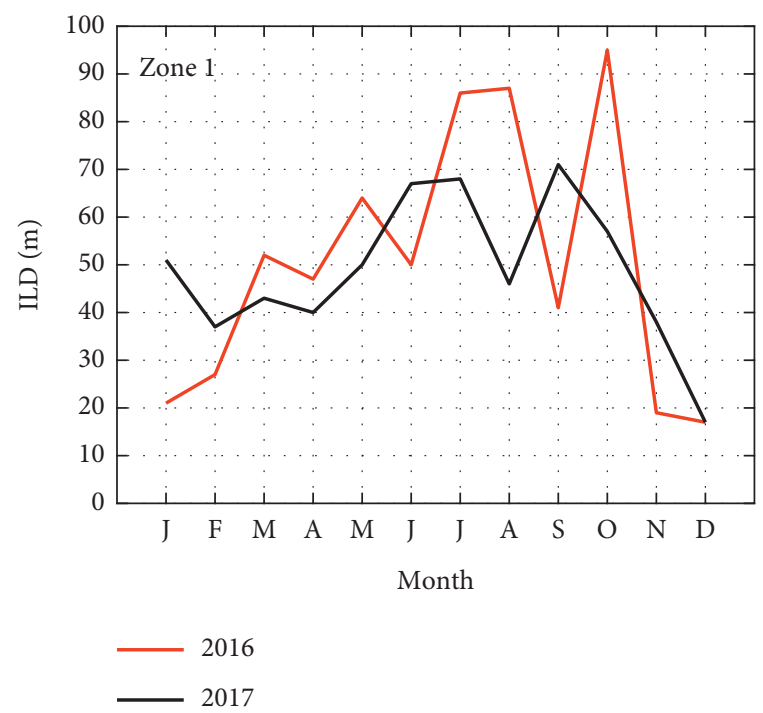

(b)

FIGURE 5: (a) Monthly mean cycle of wind speed at $10 \mathrm{~m}$ above sea surface in the south Arabian Sea (Zone 1) during 2016-17 based on WHOI Objectively Analyzed Air-Sea Fluxes project datasets. (b) Monthly mean cycle of ILD amplitude $\left(\Delta T=1^{\circ} \mathrm{C}\right)$ derived from Argo datasets.
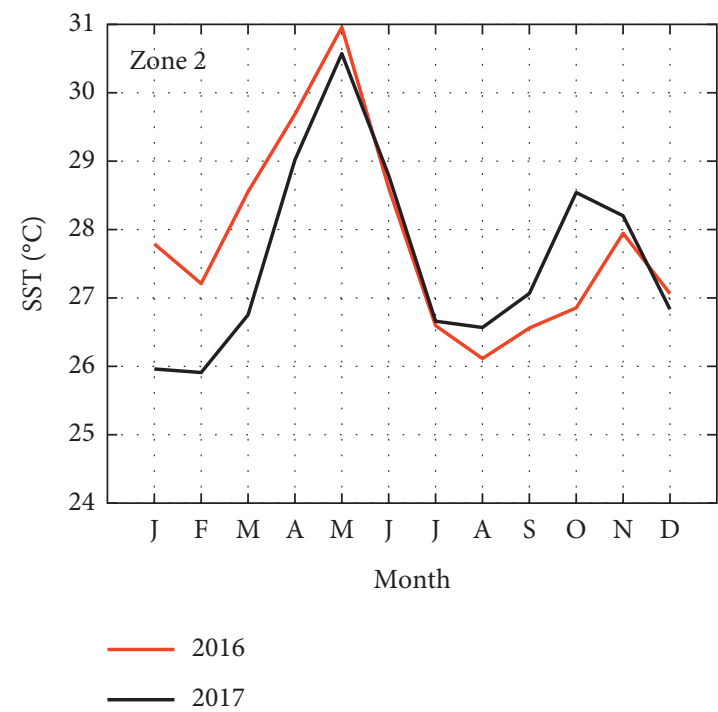

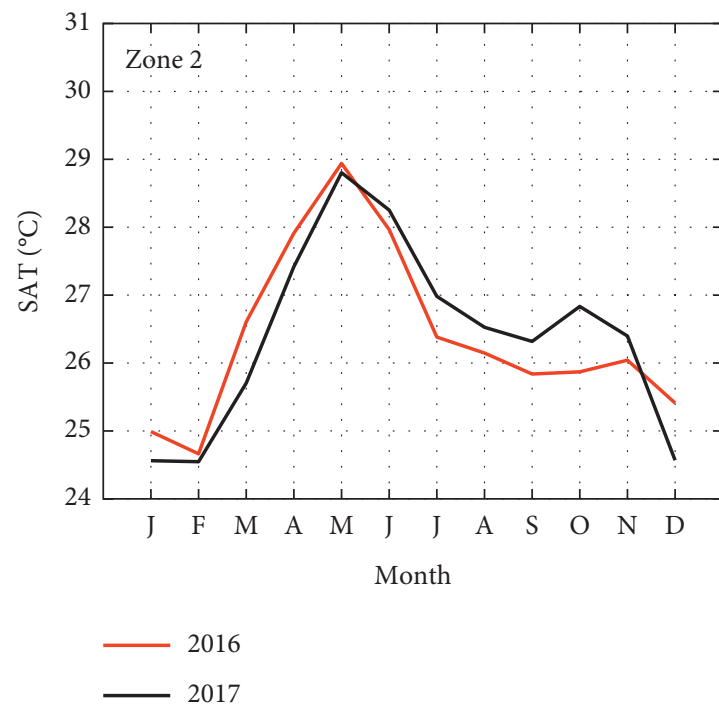

(b)

Figure 6: As in Figure 4, but for the central Arabian Sea (Zone 2). (a) Monthly mean cycle of SST. (b) Monthly mean cycle of SAT.

August 2016 due to high wind speed (WS $>9 \mathrm{~m} / \mathrm{s}$ ) and cooling in the air temperature $\left(\sim 26.5^{\circ} \mathrm{C}\right)$ (see Figure $\left.8(\mathrm{~b})\right)$.

On the seasonal average, the summer monsoon warming is not similar and shows different variability in both 2016 and 2017. The two-year distribution shows that the winter warming of SST is almost equal for both 2016 and 2017; however, significant variations in the SST cycle are observed during the summer monsoon months (July to September), where about $1.5^{\circ} \mathrm{C}$ decrease (increase) in SST is recorded in 2016 (2017) (Figure 8(a)). The wind speed was slightly high in 2016 than in 2017 summer months. The cooling (warming) in SST in 2016 (2017) is most probably due to the summer increased (reduced) upwelling that occurred along the western coast of the Arabian
Sea near Ras al Hadd region around $22^{\circ} \mathrm{N}, 64^{\circ} \mathrm{E}$ band. The warmer ocean temperatures add more moisture to the atmosphere due to increased evaporation and latent heat, contributing to more rainfall and flooding in Bangladesh during the summer of 2017 [13, 40]. On the other hand, the strong upwelling along the Oman-Arabian coast pulled the cold water up and shallow the thermocline depth in summer of 2016 (ILD $\sim$ 30min August-September 2016; Figure 10(b)).

3.4. Sea of Oman. The monthly cycle of SST and SAT in the Sea of Oman region in 2016 and 2017 is shown in Figures $11(\mathrm{a})$ and $11(\mathrm{~b})$, respectively. In this region, the 


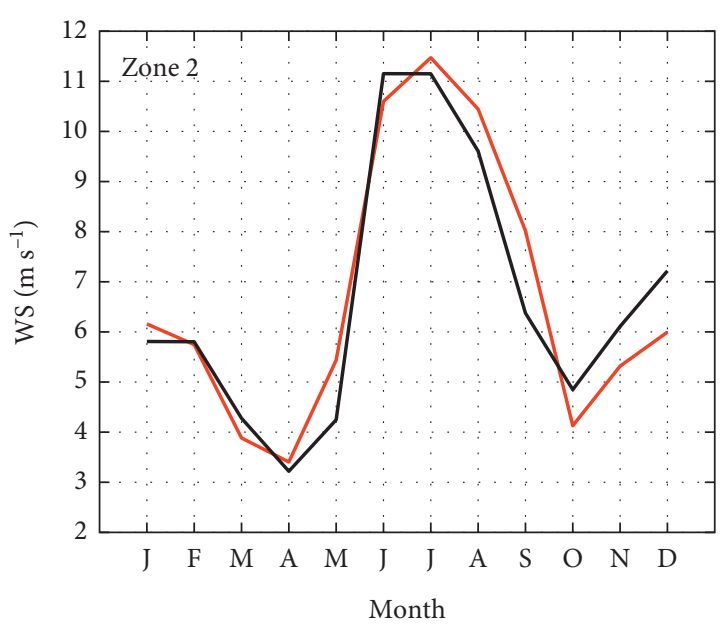

2016

2017

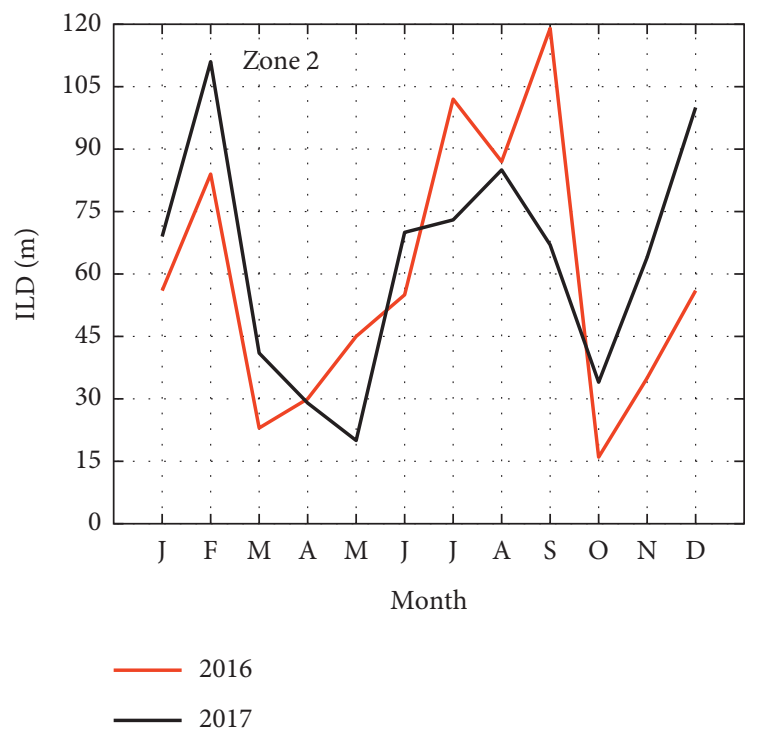

(b)

Figure 7: As in Figure 5, but for the central Arabian Sea (Zone 2). (a) Monthly mean of WS at $10 \mathrm{~m}$ above sea surface. (b) Monthly mean cycle of IDL (m).

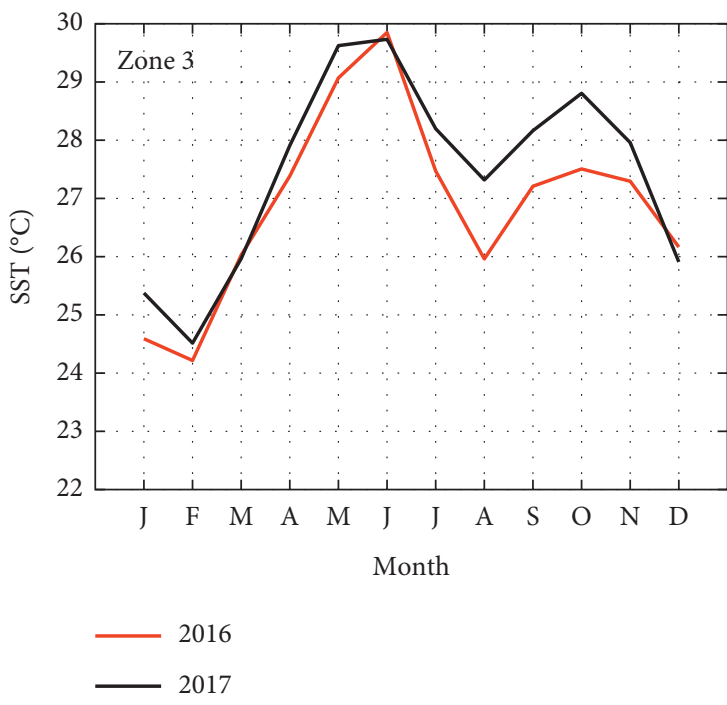

(a)

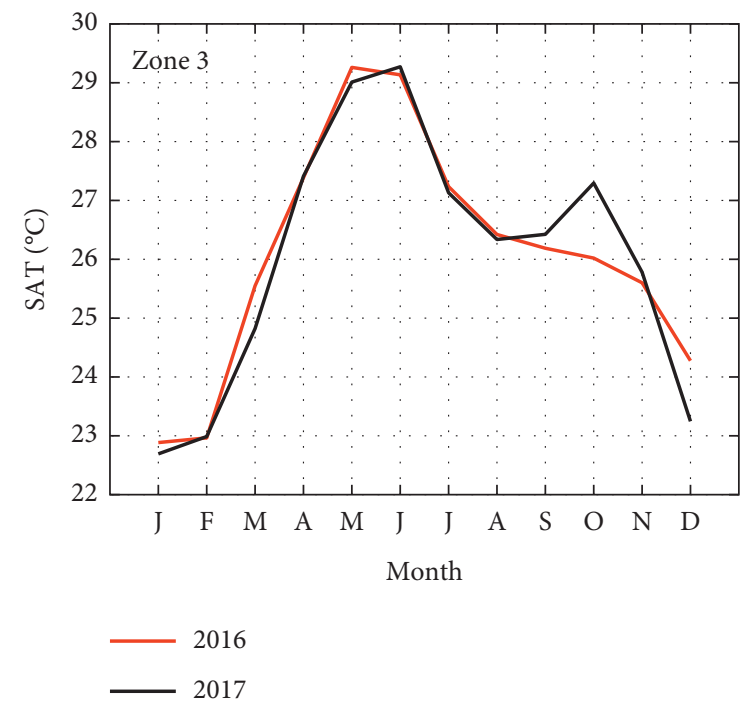

(b)

Figure 8: As in Figure 4, but for the north Arabian Sea (Zone 3). (a) Monthly mean cycle of SST. (b) Monthly mean cycle of SAT.

seasonal cycle of temperature variations in the upper sea surface is characterized by cooling during the winter monsoon (December to March) and predominantly warming in the summer monsoon (June to September). SST remains cool during the winter monsoon, with minimum sea and air temperatures at around $23.8^{\circ} \mathrm{C}$ and $22^{\circ} \mathrm{C}$, respectively (in February 2017). However, there is a steady increase in SST during the premonsoon period (April to May) due to clear skies, reduced winds, and a rise in solar insolation. These moderate winds and strong surface heating are instrumental in warming up the ocean surface starting from $25^{\circ} \mathrm{C}$ in April 2017 and reaching $31^{\circ} \mathrm{C}$ in May 2017 (Figure 11(a)).
Upon the arrival of the summer monsoon, SST warms up to $31^{\circ} \mathrm{C}$ in August 2016 and June 2017 with SSS above 36.2 each (see Figure 12(d)). The presence of high salinity water $(>36.5)$ in the Sea of Oman is most probably due to excess evaporation over precipitation and highly saline water intrusion from the Persian Gulf during the summer monsoon ([39]; see Figure 13(d)). The postmonsoon period in this region is characterized by the departure of the summer monsoon, having almost similar characteristics of surface forcing as that of premonsoon. SST starts to gradually decrease again and reaches the second low of $26.1^{\circ} \mathrm{C}$ in October 2016.

The two-year distribution of SST in the Sea of Oman region reveals that the winter warming is almost similar for 


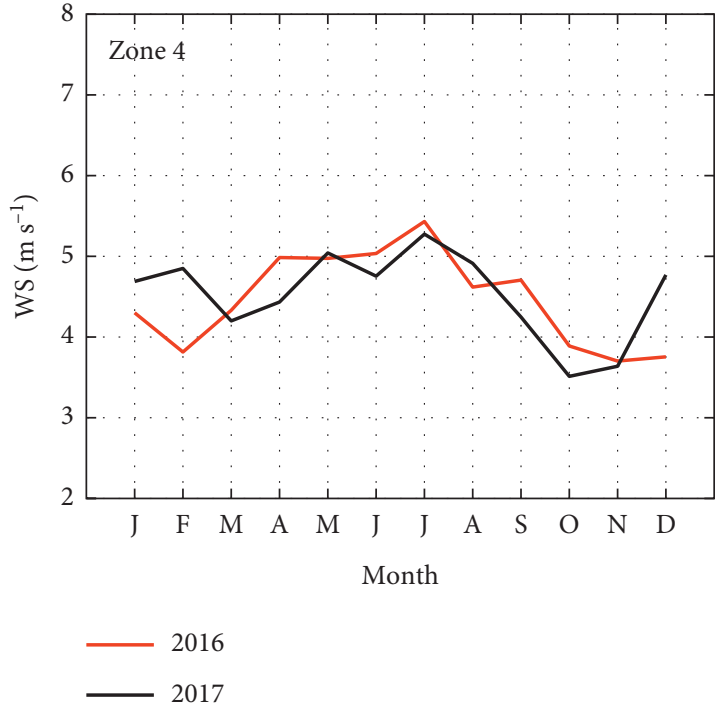

(a)

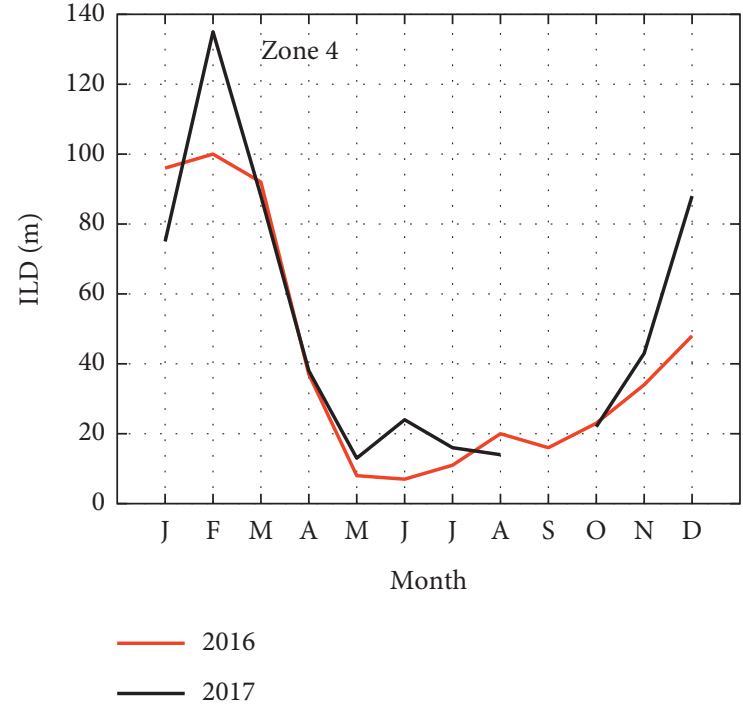

(b)

Figure 9: As in Figure 5, but for the Sea of Oman (Zone 4). The discontinue line in (b) is the missing data in the Argo datasets in this region. (a) Monthly mean of WS at $10 \mathrm{~m}$ above sea surface. (b) Monthly mean cycle of IDL (m).

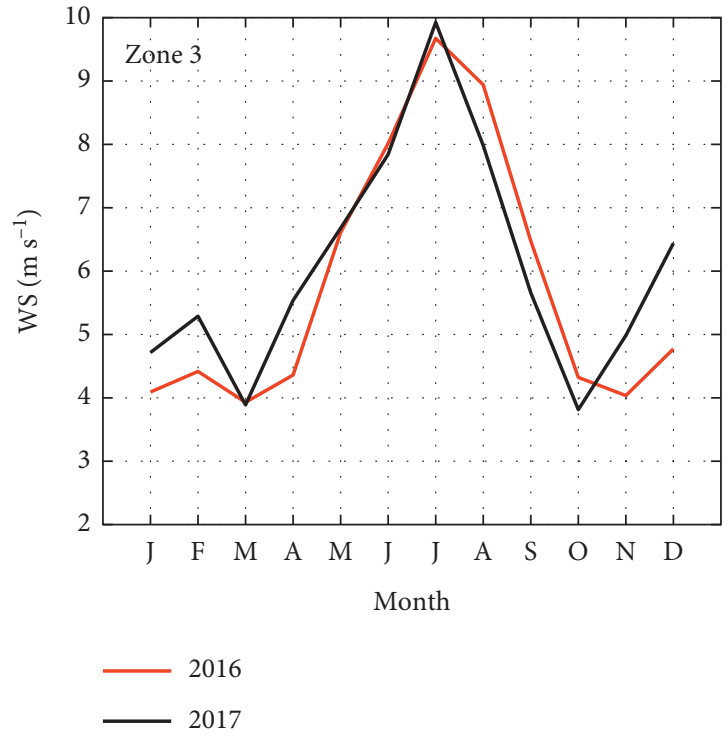

(a)

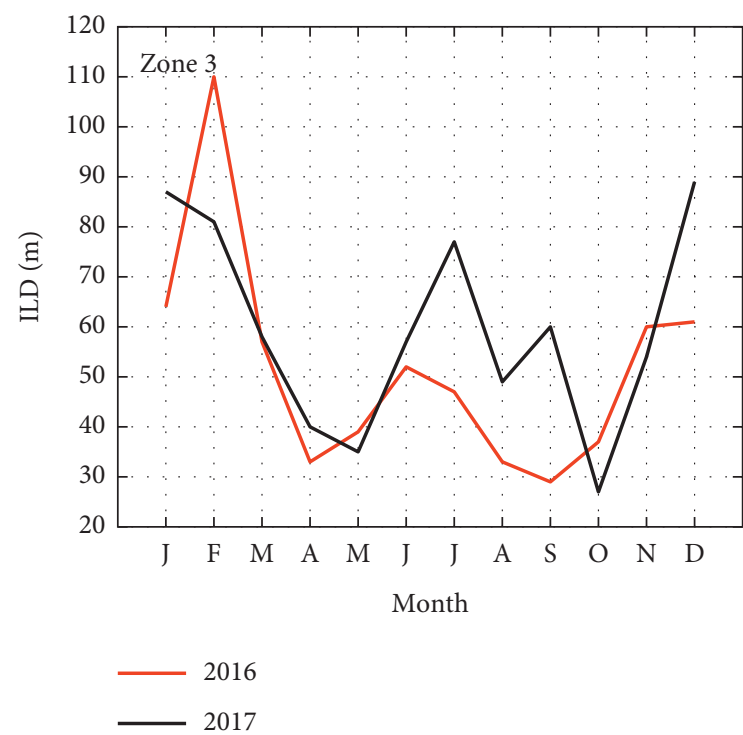

(b)

Figure 10: As in Figure 5, but for the north Arabian Sea (Zone 3). (a) Monthly mean of WS at 10 m above sea surface. (b) Monthly mean cycle of IDL (m).

both years; however, a significant change in the SST cycle is observed during the premonsoon month (May) and the first half of summer monsoon (June to July). As can be seen from Figure 11(a), an abrupt cooling in SST up to $3^{\circ} \mathrm{C}$ is recorded in 2016 from May to July. This fall in temperature is due to the annual upwelling events, which occur along the southern coast of Oman near the Ras al Hadd region between $22.5^{\circ} \mathrm{N}$ and $59.5^{\circ} \mathrm{E}$ band (figure is not shown). This is because the upwelling water of about $25^{\circ} \mathrm{C}$ may originate below the pycnocline and, therefore, is colder than the surface water, which is $29^{\circ} \mathrm{C}$ or more and forms a shallow thermocline around 5 to $10 \mathrm{~m}$ deep (see Figure 9(b)). The depth of the thermocline, however, varies from the sea surface depending on tides and the direction, as well as the speed of coastal winds and currents. This falling trend in SST in the Sea of Oman during summer has been confirmed by other researchers [41-45]. Recently, Watanabe et al. [46] observed an abrupt SST fall in summer during various years in the Sea of Oman based on in situ SST data. The vertical profile of seawater temperature gathered by temperature sensors in 2010 also suggests that the thermocline was closer to the surface during summer upwelling events. Additionally, in 


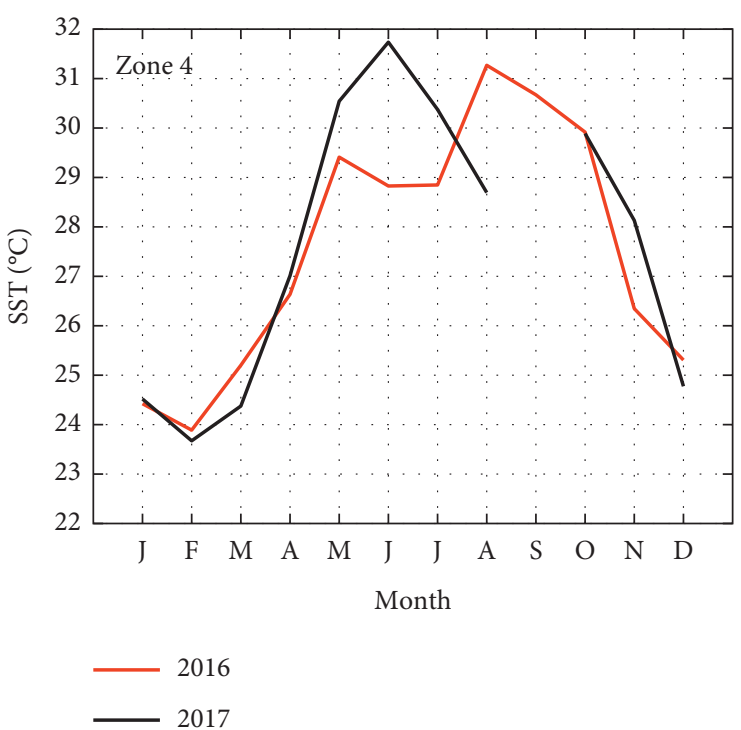

(a)

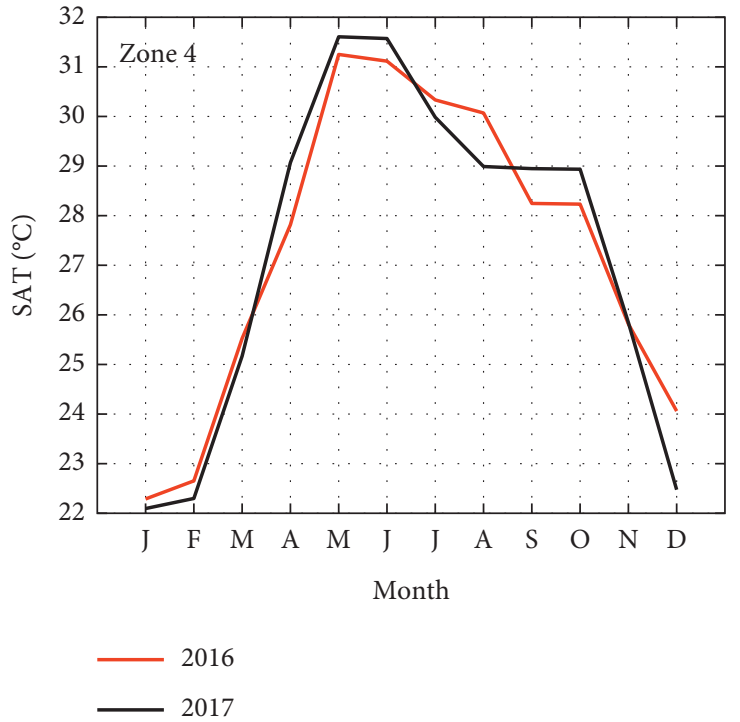

(b)

Figure 11: As in Figure 4, but for the Sea of Oman (Zone 4). The discontinue line in (a) is the missing data in the Argo datasets in this region. (a) Monthly mean cycle of SST. (b) Monthly mean cycle of SAT.

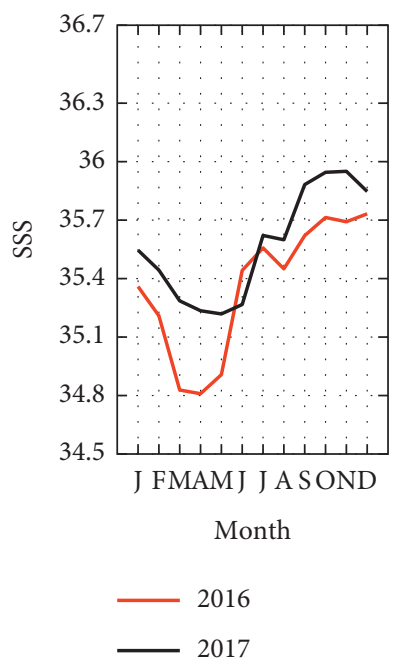

(a)

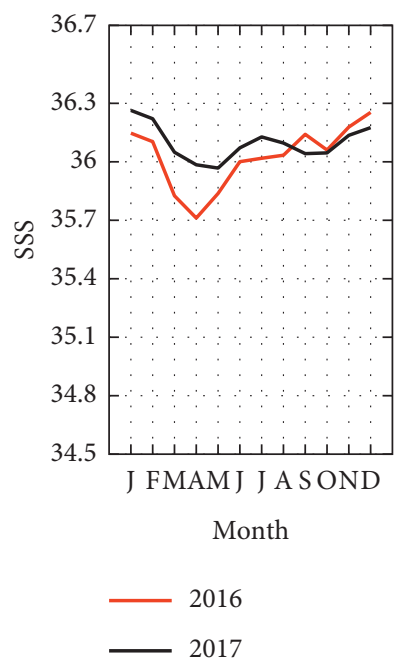

(b)

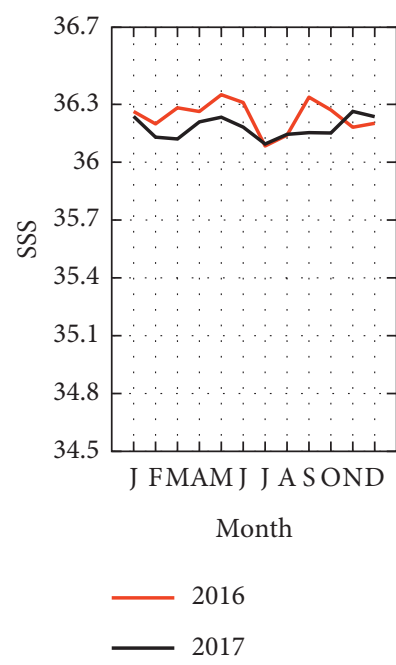

(c)

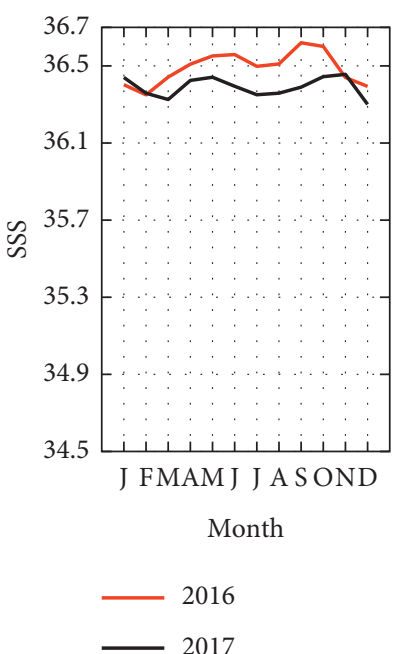

(d)

Figure 12: Monthly cycle of sea surface salinity (SSS) variability for 2016 and 2017 in Zone 1 (a), Zone 2 (b), Zone 3 (c), and Zone 4 (d). The data are obtained from the SMAPv3 (Soil Moisture Active Passive version 3) project.

situ chlorophyll-a and satellite-based SST confirmed that upwelling also occurred in July 2008 [47]. They observed a variation in the cold water near $20^{\circ} \mathrm{C}$ that underlies the solarheated surface water of $30^{\circ} \mathrm{C}$ or more and found a short thermocline at a depth of $5-15 \mathrm{~m}$. The upwelling phenomenon that occurs during the summer usually affects the SST and is the key environmental factor restricting coral growth and reef development along the southern coast of Oman from Dhofar to Ras al Hadd [48].

3.5. Precipitation Variability and SSS Circulation. The monthly mean precipitations ( $\mathrm{mm} /$ day) in Zone 1 to 4 for
2016 and 2017 are shown in Figures 13(a)-13(d), respectively. The corresponding variability in SSS is shown in Figures 12(a)-12(d), respectively, for Zones 1 to 4 .

The two-year distribution in the south Arabian Sea region shows a high precipitation rate $(\mathrm{mm} /$ day) in early 2016 than in 2017 (Figure 13(a)). The corresponding effect on SSS can be clearly seen in Figure 12(a), in which low SSS is observed at the beginning of 2016. The presence of high SSS during the winter and presummer monsoons expresses a negative P-E (precipitation minus evaporation) or strong evaporation and is characterized by low rainfall during 2017 compared to 2016. The summer monsoon, however, reveals reduced precipitation in this region in both 2016 and 2017. 


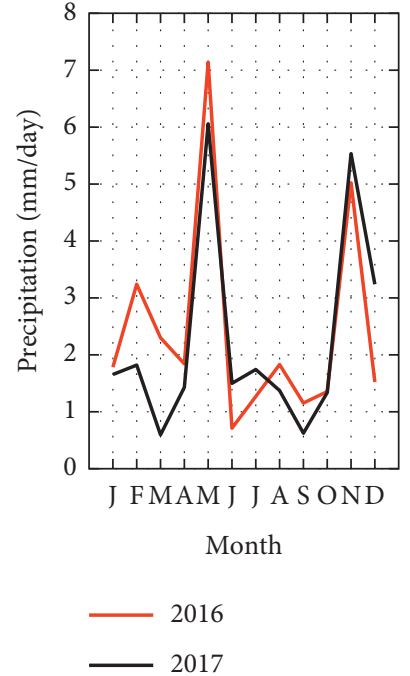

(a)

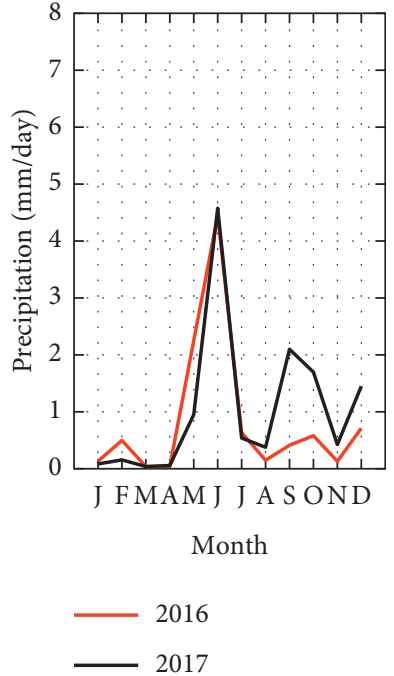

(b)

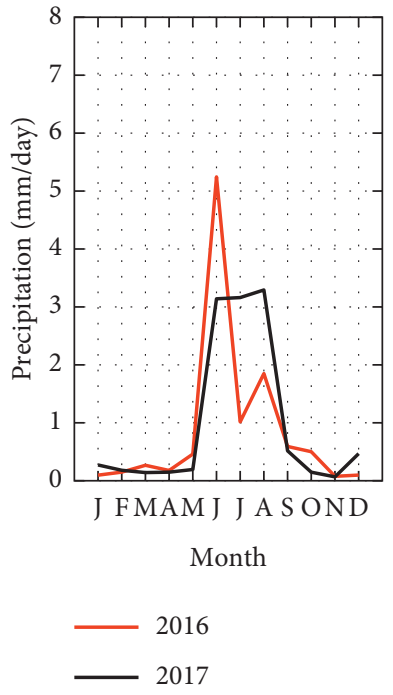

(c)

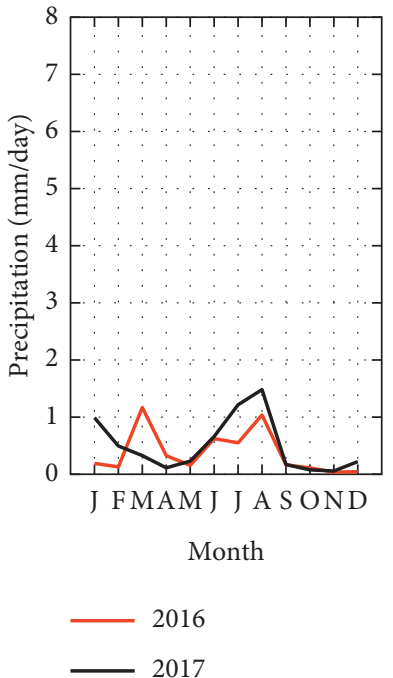

(d)

Figure 13: Monthly mean precipitation rate (mm/day) for 2016 and 2017 in Zone 1 (a), Zone 2 (b), Zone 3 (c), and Zone 4 (d). The data are provided by GPCPv2.3 for reanalysis and available at $2.5^{\circ} \times 2.5^{\circ}$ resolution.

The moderate precipitation rate in this region in JuneOctober in 2016 is mainly due to the strong negative IOD, which brought drought conditions in East Africa and reduced East African Short Rains (EASR) from October to December. These observations are consistent with $\mathrm{Lu}$ et al. (2018) [14], who recently investigated about $1 \mathrm{~mm} /$ day reduction in EASR in 2016, with a 50\% reduction in normal rainfall in some regions.

On a seasonal scale, the monthly rainfall pattern for both winter and summer monsoons in the central Arabian Sea is low compared to the south Arabian Sea region; however, higher SSS ( $>36$ on average) is observed over the entire period (see Figures 13(b)and 9(b)). The two-year distribution shows a slight increase in precipitation during the 2016 winter monsoon compared to 2017. The low SSS is most likely due to excess precipitation in the early months of 2016 compared to 2017. The presummer and first half of the summer monsoon show almost similar precipitation patterns but significantly reduced from the south basin in both 2016 and 2017. The subsurface high saline water $(>36.9)$ at a depth of about $80 \mathrm{~m}$ observed from May to June 2017 at a latitude of $13^{\circ} \mathrm{N}$ (figure is not shown) is mainly due to the excess evaporation over precipitation during summer and the intrusion of Red Sea Outflow Water ( $>40)$ into the Arabian Sea via the Gulf of Aden [48-50].

On an annual average, the Bay of Bengal region expresses above average rainfall in both years with an increased trend in 2017, consistent with SST warming in the north Arabian Sea region due to low upwelling along the Oman-Arabian coast in summer 2017 (Figure 14). However, evidence of precipitation increase with SST, in the Arabian Sea, is not observed (Figure 15). It is interesting to mention here that SST was warmed by the weak upwelling that occurred along the Oman-Arabian coast in summer of 2017, which led to an increased rainfall in the west coast of Indian and western Bay of Bengal [51]. The low (high) precipitation, shown in Figure 13(b) in 2016 (2017), is concurrent with negative (positive) IOD and consistent with the results of Chanda et al. 2018 [52].

The monthly mean precipitation in the Arabian Sea and Sea of Oman regions indicates that the south Arabian Sea region is strongly influenced by the monsoon cycle with increased precipitation rate (Figure 13). However, a decreasing trend is observed towards north of the equator with minimum precipitation rate in the Sea of Oman region, meaning that this region is less influenced by the monsoon. Interestingly, a similar but opposite trend is observed in SSS circulation in these regions (Figure 12). For SSS circulation, it is perceived that the presence of highly saline water in the north and central basins of the Arabian Sea was due to excess evaporation over precipitation and intrusion of high saline water from two marginal seas: the Persian Gulf and the Red Sea. On the other side, seawater at the south Arabian Sea was significantly less in saline $(<35)$ than that of central and north Arabian Sea regions. This decrease in salinity was mostly because of positive P-E (precipitation minus evaporation) or strong precipitation near the equator and intrusion of less saline water from the Bay of Bengal. It clearly indicates the coexistence of two water masses in the Arabian Sea region: (1) the Arabian Sea High Salinity Water 


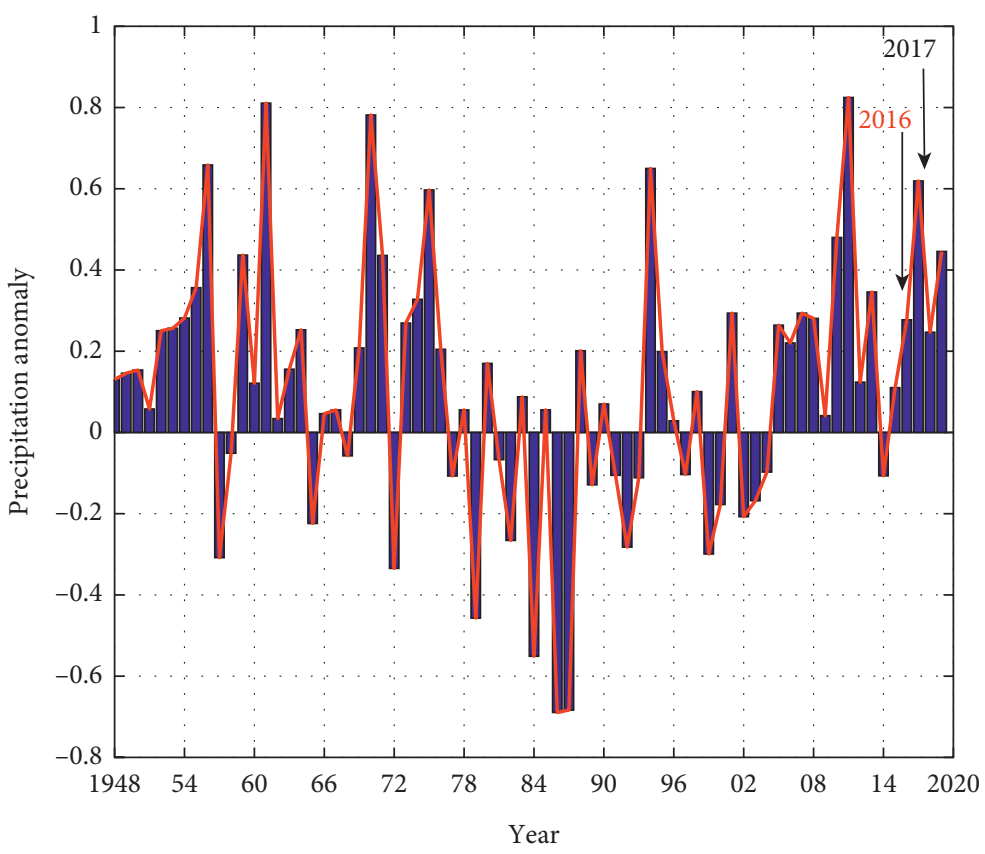

(a)

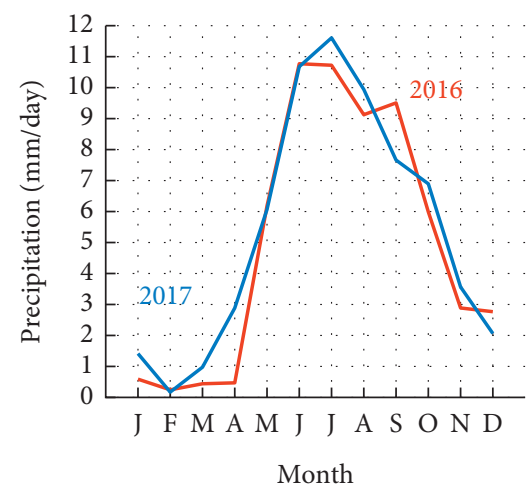

(b)

Figure 14: (a) Time series dataset of precipitation anomaly (1948-2019) in the Bay of Bengal (10-20 $\left.\mathrm{N}, 80-100^{\circ} \mathrm{E}\right)$. The anomaly datasets are obtained from the NOAA precipitation reconstruction (PREC) project. (b) The monthly mean precipitation in 2016 and 2017 in the Bay of Bengal region.

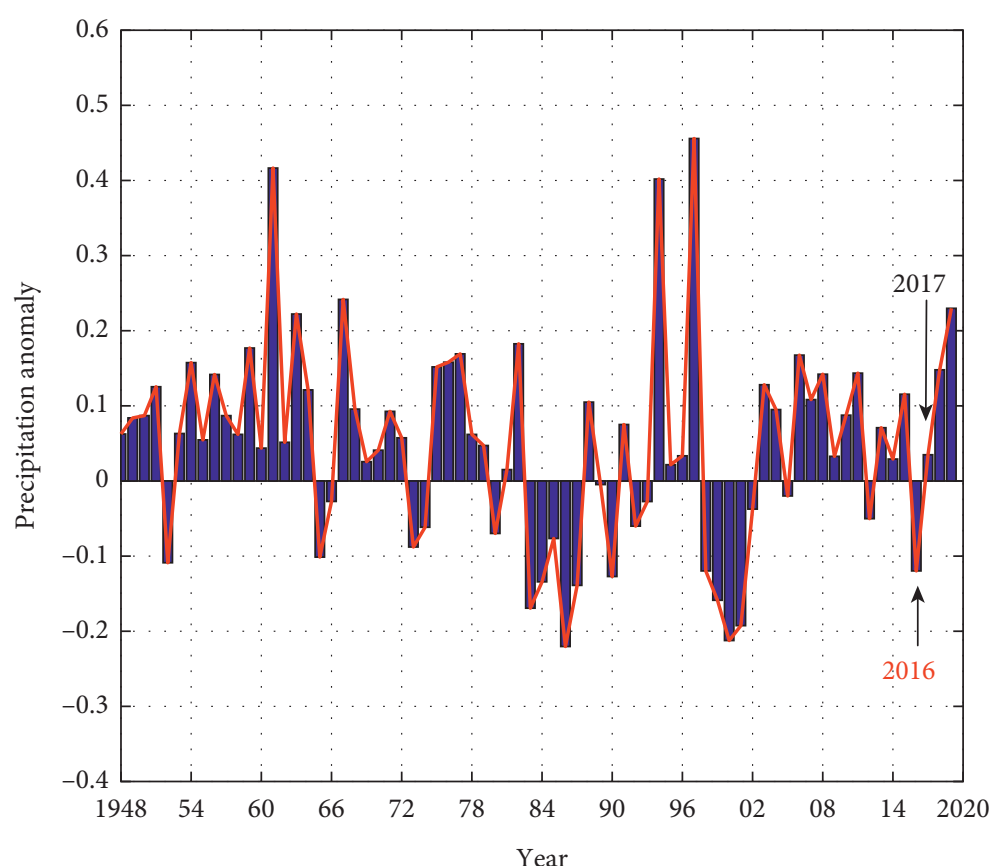

(a)

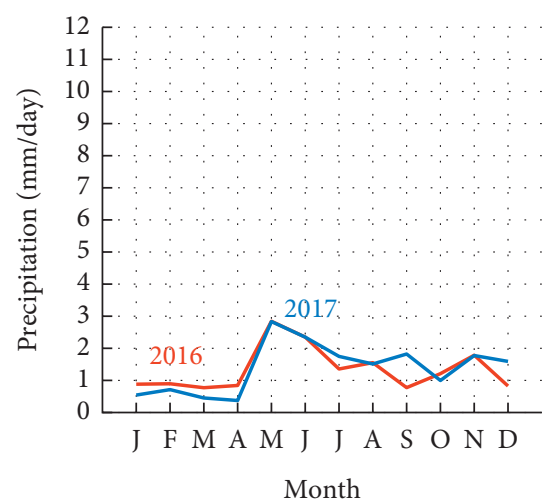

(b)

Figure 15: As in Figure 14, but for the Arabian Sea region. (a) Arabian Sea (Eq-25 N, 50-70 E). (b) Arabian Sea. 
(ASHSW) that is in excess of salinity (>36.9) and occupying the North and Central basins of the Arabian Sea and (2) the Bay of Bengal Water (BBW) that was lower in salinity $(<35)$ and occupying the south basin of the Arabian Sea [53].

\section{Summary and Conclusions}

The present research has demonstrated the capability of Satellite and Argo datasets and their effectiveness in observing the upper-ocean thermal structure variability. The dynamics and behavior of the Arabian Sea are different from other seas of the world oceans, as it is situated at the intersection of all the three oceans and is highly exposed to the tropical climate. The present study provides a detailed description of the SST and ILD variability in association with the monsoon cycle, as this may have a significant impact on summer monsoon qualitative predictability (meaning the prediction of a weaker or stronger summer monsoon relative to the climatological mean) in the tropical oceans. In addition, adequate information on the climatological spacetime variability in SST and ILD and the forcing mechanisms that determine this variability would provide critical information for oceanographers and modelers of space-time upper-ocean thermal structure variations in a region of important air-sea interaction.

On the seasonal average, we investigated that the winter monsoon warming in the south-central basin of the Arabian Sea was not similar and showed different variability in SST in both 2016 and 2017. The significant variability observed in the SST cycle in the south-central basin was the result of a large-scale dynamic such as El Niño in the Pacific Ocean that occurred in early 2016 [12]. In addition, we have noticed significant cooling (warming) in the SST cycle during the summer of 2016 (2017) in the south-central regions. This cooling (warming) in SST during the summer is associated with the evolution of extreme negative (weak positive) IOD events that occurred in the summer of 2016 (2017) and affected the western Indian Ocean with negative (positive) SST anomalies $[4,12,13]$. A notable feature of the SST cycle in the Arabian Sea and Sea of Oman regions is the existence of a strong upwelling along the Oman-Arabian coast that occurred during summer season. Most of the SST variability in the Sea of Oman and the north basin of the Arabian Sea was basically due to annual signatures of small-scale variations, especially along the Oman-Arabian coast near Ras al Hadd region that occurred in late spring and peak in summer. In short, it can be summarized that the dynamic mechanism of seasonal variations in the SST cycle in the Arabian Sea and Sea of Oman regions can be either the result of large-scale interannual atmospheric force such ENSO in the Pacific Ocean and internal independent ocean mechanism such as IOD or the annual signatures of the oceanic mesoscale variations that have occurred along the OmanArabian coastlines.

Surprisingly, quite different behavior was seen in the south-central Arabian Sea regions, where the ILD amplitude was always smaller in the winter monsoon and larger in the summer and postmonsoons. The smaller ILD amplitude in December to March indicated the weaker nature of the convective mixing during the winter monsoon, while larger amplitude in June to September represents the dominant nature of the winds stirring and Ekman pumping during the summer monsoon. On the other side, the emergence of thinner ILD amplitude in the summer monsoon is most probably due to the absence of wind action in the Sea of Oman region. The larger SST peaks and smaller ILD amplitudes during the summer monsoon period indicated that the Sea of Oman was shielded to some extent from the monsoons. In short, it can be summarized that, during the summer monsoon, winds forcing plays a significant role in mixing and deepening of ILD, where the convective fluxing or Ekman pumping were the essential dynamics that were responsible for deeper ILD during the winter monsoon. Consequently, out of four zones, the central Arabian Sea was strongly influenced by summer monsoon winds, where ILD was larger in amplitude with smaller SST peaks, while, on the other side, the Sea of Oman region showed smaller ILD amplitude with larger SST peaks and was, therefore, weakly affected by the monsoon. In this study, we provided sufficient information to predict the strength of a stronger or weaker monsoon from ILD amplitude, with space and time changing in the Arabian Sea and Sea of Oman regions. However, the prediction of large-scale dynamics and the impact of other ocean basins affecting the monsoon cycle, which are responsible for extreme weather conditions in the Arabian Sea, is still less explored and needs to be addressed in future research.

\section{Data Availability}

The Argo datasets are freely available online and can be downloaded from the website www.argo.ucsd.edu. The monthly mean SST and SST anomaly datasets are obtained from NOAA OISST (Optimum Interpolation Sea Surface Temperature) blended product, version 2.1. The monthly mean wind speed datasets are provided by the OAFlux project and available online at http://oaflux.whoi.edu. The long time precipitation datasets (1948-2019) are obtained from the NOAA precipitation reconstruction (PREC).

\section{Conflicts of Interest}

The authors declare no conflicts of interest.

\section{Acknowledgments}

The authors are thankful to the International Argo Project, NCEP Global Data Assimilation System (GDAS), Global Precipitation Climatology Project (GPCP), WHOI Objectively Analyzed Air-Sea Fluxes (OAFlux) project, and SMAPv3 (Soil Moisture Active Passive version 3) for providing the data. They wish to acknowledge the Acoustic Science and Technology Laboratory of Harbin Engineering University for analysis and graphics. This work was supported by an International Postgraduate Scholarship awarded by the Chinese Scholarship Council and National Key Research and Development Program of China (no. 2016YFC1400100). 


\section{References}

[1] G. T. Walker, "Correlation in seasonal variations of weather. IX. A further study of world weather," Memoirs of the Indian Meteorological Department, vol. 24, no. Part 9, pp. 275-332, 1924.

[2] V. Krishnamurthy and J. Shukla, "Intraseasonal and interannual variability of rainfall over India," Journal of Climate, vol. 13, no. 24, pp. 4366-4377, 2000.

[3] K. Arpe, L. Dümenil, and M. A. Giorgetta, "Variability of the Indian monsoon in the ECHAM3 model: sensitivity to sea surface temperature, soil moisture, and the stratospheric quasi-biennial oscillation," Journal of Climate, vol. 11, no. 8, pp. 1837-1858, 1998.

[4] S. Khan, S. Piao, G. Zheng et al., "Sea surface temperature variability over the tropical Indian Ocean during the ENSO and IOD events in 2016 and 2017," Atmosphere, vol. 12, no. 5, p. $587,2021$.

[5] P. J. Webster, A. M. Moore, J. P. Loschnigg, and R. R. Leben, "Coupled ocean-atmosphere dynamics in the Indian Ocean during 1997-98," Nature, vol. 401, no. 6751, pp. 356-360, 1999.

[6] N. H. Saji, B. N. Goswami, P. N. Vinayachandran, and T. Yamagata, "A dipole mode in the tropical Indian Ocean," Nature, vol. 401, no. 6751, pp. 360-363, 1999.

[7] R. Murtugudde, J. P. McCreary Jr, and A. J. Busalacchi, "Oceanic processes associated with anomalous events in the Indian Ocean with relevance to 1997-1998," Journal of Geophysical Research: Oceans, vol. 105, no. C2, pp. 3295-3306, 2000.

[8] G. Reverdin, D. L. Cadet, and D. Gutzler, "Interannual displacements of convection and surface circulation over the equatorial Indian Ocean," Quarterly Journal of the Royal Meteorological Society, vol. 112, no. 471, pp. 43-67, 1986.

[9] R. Murtugudde, R. Seager, and P. Thoppil, "Arabian Sea response to monsoon variations," Paleoceanography, vol. 22, no. $4,2007$.

[10] D. W. A. Leetmaa, "Arabian Sea cooling a preliminary heat budget," Oceanosraphy, vol. 10, pp. 307-312, 1980.

[11] J. Shukla, "Effect of Arabian sea-surface temperature anomaly on Indian summer monsoon: a numerical experiment with the GFDL model," Journal of the Atmospheric Sciences, vol. 32, no. 3, pp. 503-511, 1975.

[12] World Meteorological Organization (WMO), Statement on the State of the Global Climate in 2016, WMO, Geneva, Switzerland, 2016.

[13] World Meteorological Organization (WMO), Statement on the State of the Global Climate in 2017, WMO, Geneva, Switzerland, 2017.

[14] B. Lu, H. L. Ren, A. A. Scaife et al., "An extreme negative Indian Ocean Dipole event in 2016: dynamics and predictability," Climate Dynamics, vol. 51, no. 1-2, pp. 89-100, 2018.

[15] F. Ninove, P. Y. Le Traon, E. Remy, and S. Guinehut, "Spatial scales of temperature and salinity variability estimated from Argo observations," Ocean Science, vol. 12, p. 7, 2016.

[16] D. Roemmich, G. Johnson, S. Riser et al., "The Argo Program: observing the global oceans with profiling floats," Oceanography, vol. 22, no. 2, pp. 34-43, 2009.

[17] B. Zhang, Y. Liu, D. Shang, and I. U. Khan, "A method for predicting radiated acoustic field in shallow sea based on wave superposition and ray," MDPI Applied Sciences, vol. 10, no. 3, pp. 1-13, 2020.

[18] http://www.ifremer.fr/coriolis/cdc/default.htm.
[19] J. Boutin, N. Martin, X. Yin, J. Font, N. Reul, and P. Spurgeon, "First assessment of SMOS data over open ocean: part II-sea surface salinity," IEEE Transactions on Geoscience and Remote Sensing, vol. 50, no. 5, pp. 1662-1675, 2012.

[20] R. F. Adler, G. J. Huffman, A. Chang et al., "The version-2 global precipitation climatology project (GPCP) monthly precipitation analysis (1979-present)," Journal of Hydrometeorology, vol. 4, no. 6, pp. 1147-1167, 2003.

[21] G. J. Huffman, R. F. Adler, D. T. Bolvin, and G. Gu, "Improving the global precipitation record: GPCP version 2.1," Geophysical Research Letters, vol. 36, no. 17, p. L17808, 2009.

[22] T. Meissner, F. J. Wentz, and D. M. L. Vine, "The salinity retrieval algorithms for the NASA aquarius version 5 and SMAP version 3 releases," Remote Sensing, vol. 10, no. 7, p. 1121, 2018.

[23] A. B. Kara, P. A. Rochford, and H. E. Hurlburt, "Mixed layer depth variability over the global ocean," Journal of Geophysical Research: Oceans, vol. 108, no. C3, p. 571, 2003.

[24] K. H. Bathen, "On the seasonal changes in the depth of the mixed layer in the North Pacific Ocean," Journal of Geophysical Research, vol. 77, no. 36, pp. 7138-7150, 1972.

[25] P. Lamb, "On the mixed-layer climatology of the north and tropical Atlantic," Tellus, vol. 36, pp. 292-305, 1984.

[26] R. R. Rao, R. L. Molinari, and J. F. Festa, "Evolution of the climatological near-surface thermal structure of the tropical Indian Ocean: 1. Description of mean monthly mixed layer depth, and sea surface temperature, surface current, and surface meteorological fields," Journal of Geophysical Research, vol. 94, no. C8, pp. 10801-10815, 1989.

[27] R. R. Rao and R. Sivakumar, "Seasonal variability of sea surface salinity and salt budget of the mixed layer of the north Indian Ocean," Journal of Geophysical Research: Oceans, vol. 108, no. C1, pp. 9-14, 2003.

[28] A. B. Kara, P. A. Rochford, and H. E. Hurlburt, "Mixed layer depth variability and barrier layer formation over the North Pacific Ocean," Journal of Geophysical Research: Oceans, vol. 105, no. C7, pp. 16783-16801, 2000.

[29] N. K. Vissa, A. N. V. Satyanarayana, and B. Prasad Kumar, "Comparison of mixed layer depth and barrier layer thickness for the Indian Ocean using two different climatologies," International Journal of Climatology, vol. 33, no. 13, pp. 28552870, 2013.

[30] K. Wyrtki, "The thermal structure of the eastern Pacific Ocean," Deutschen Hydrographischen Zeitschrift, Erga"nzungsheft A, vol. 8, pp. 6-84, 1964.

[31] J. F. Price, R. A. Weller, and R. Pinkel, "Diurnal cycling: observations and models of the upper ocean response to diurnal heating, cooling, and wind mixing," Journal of Geophysical Research, vol. 91, no. C7, pp. 8411-8427, 1986.

[32] J. Sprintall and M. Tomczak, "Evidence of the barrier layer in the surface layer of the tropics," Journal of Geophysical Research, vol. 97, no. C5, pp. 7305-7316, 1992.

[33] S. Hosoda, T. Ohira, K. Sato, and T. Suga, "Improved description of global mixed-layer depth using Argo profiling floats," Journal of Oceanography, vol. 66, no. 6, pp. 773-787, 2010.

[34] R. O. R. Y. Thompson, "Climatological numerical models of the surface mixed layer of the ocean," Journal of Physical Oceanography, vol. 6, no. 4, pp. 496-503, 1976.

[35] C. de Boyer Montégut, G. Madec, A. S. Fischer, A. Lazar, and D. Iudicone, "Mixed layer depth over the global ocean: an examination of profile data and a profile-based climatology," Journal of Geophysical Research: Oceans, vol. 109, no. C12, 2004. 
[36] C. de Boyer Montégut, J. Mignot, A. Lazar, and S. Cravatte, "Control of salinity on the mixed layer depth in the world ocean: 1. General description," Journal of Geophysical Research: Oceans, vol. 112, no. C6, 2007.

[37] B. An, C. Zhang, D. Shang, Y. Xiao, and I. U. Khan, “A combined finite element method with normal mode for the elastic structural acoustic radiation in shallow water," Journal of Theoretical and Computational Acoustics, vol. 28, no. 4, Article ID 2050004, 2020.

[38] M. Tomczak and J. S. Godfrey, Regional Oceanography: An Introduction, Elsevier, Amsterdam, Netherlands, 2013.

[39] S. Khan, S. Yang, X. Bingchen, D. Bradley, N. Ahmed, and P. Shengchun, "Subsurface highly saline water variability in the Gulf of Oman," OCEANS 2019-Marseille, pp. 1-4, IEEE, Marseille, France, 2019.

[40] P. S. Suthinkumar, C. A. Babu, and H. Varikoden, "Spatial distribution of extreme rainfall events during 2017 southwest monsoon over Indian subcontinent," Pure and Applied Geophysics, vol. 176, no. 12, pp. 5431-5443, 2019.

[41] N. Quinn and D. Johnson, "Cold water upwellings cover Gulf of Oman coral reefs," Coral Reefs-Journal of the International Society for Reef Studies, vol. 15, no. 4, p. 214, 1996.

[42] S. L. Coles, "Reef corals occurring in a highly fluctuating temperature environment at Fahal Island, Gulf of Oman (Indian Ocean)," Coral Reefs, vol. 16, no. 4, pp. 269-272, 1997.

[43] J. Wiggert, R. Hood, K. Banse, and J. Kindle, "Monsoondriven biogeochemical processes in the Arabian Sea," Progress in Oceanography, vol. 65, no. 2-4, pp. 176-213, 2005.

[44] M. R. Claereboudt, Reef Corals and Coral Reefs of the Gulf of Oman, Historical Association of Oman, Oman, 2006.

[45] T. Watanabe, A. Suzuki, S. Minobe et al., "Permanent El Niño during the Pliocene warm period not supported by coral evidence," Nature, vol. 471, no. 7337, pp. 209-211, 2011.

[46] T. K. Watanabe, T. Watanabe, A. Yamazaki, M. Pfeiffer, D. Garbe-Schönberg, and M. R. Claereboudt, "Past summer upwelling events in the Gulf of Oman derived from a coral geochemical record," Scientific Reports, vol. 7, no. 1, p. 4568, 2017.

[47] A. R. Al-Azri, S. A. Piontkovski, K. A. Al-Hashmi, J. I. Goes, and H. R. Do Gomes, "Chlorophyll a as a measure of seasonal coupling between phytoplankton and the monsoon periods in the Gulf of Oman," Aquatic Ecology, vol. 44, no. 2, pp. 449-461, 2010.

[48] A. S. Bower, H. D. Hunt, and J. F. Price, "Character and dynamics of the Red Sea and Persian Gulf outflows," Journal of Geophysical Research: Oceans, vol. 105, no. C3, pp. 63876414, 2000.

[49] A. S. Bower, W. E. Johns, D. M. Fratantoni, and H. Peters, "Equilibration and circulation of Red Sea outflow water in the Western Gulf of Aden," Journal of Physical Oceanography, vol. 35, no. 11, pp. 1963-1985, 2005.

[50] S. Pous, X. Carton, and P. Lazure, "Hydrology and circulation in the Strait of Hormuz and the Gulf of Oman results from the GOGP99 experiment: 2. Gulf of Oman," Journal of Geophysical Research: Oceans, vol. 109, no. C12, 2004.

[51] T. Izumo, C. B. Montégut, J.-J. Luo, S. K. Behera, S. Masson, and T. Yamagata, "The role of the Western Arabian Sea upwelling in Indian monsoon rainfall variability," Journal of Climate, vol. 21, no. 21, pp. 5603-5623, 2008.

[52] A. Chanda, S. Das, A. Mukhopadhyay et al., "Sea surface temperature and rainfall anomaly over the Bay of Bengal during the El niño-southern oscillation and the extreme Indian Ocean dipole events between 2002 and 2016," Remote
Sensing Applications: Society and Environment, vol. 12, pp. 10-22, 2018.

[53] C. de Boyer Montégut, F. Durand, R. Bourdallé-Badie, and B. Blanke, "Role of fronts in the formation of Arabian Sea barrier layers during summer monsoon," Ocean Dynamics, vol. 64, no. 6, pp. 809-822, 2014. 